this never, sadly, appeared, she made at least eleven significant published contributions to Smith scholarship between 1967 and 1985. Other contributions included at least eleven entries in the prestigious Dictionary of Scientific Biography over 1971-1978.

In March 1978, Victor Eyles died after a short illness during which Joan was his devoted nurse. She then faced the choice of staying in her Cotswold cottage or moving to somewhere nearer Oxford. But her commitments, whether as the senior British scholar in the field of the history of geology, as a lecturer on Smith, as a source of information to an ever-increasing circle of strangers who sought her expertise, as adviser to the Geological Society library or as a devoted conference goer, never really allowed her to face the choice.

In later years, visitors to her cottage were always assured of a warm welcome, but they noticed too she was becoming increasingly

3 Archives of Natural History (1986), 13, p. 212 shows a photograph of the occasion. side-tracked from her work on Smith by the sheer volume of her other interests and activities. She was an enthusiastic supporter of the History of the Earth Sciences Society, founded in 1981, and of the Society for the History of Natural History whose founder's medal she was delighted to receive in March 1986. ${ }^{3}$ She applied, without success, for a D.Sc. degree from her old University College in 1984. She died on 14 June 1986 after a stroke, and was cremated at Cheltenham.

Her (and Victor's) best general memorial will remain the magnificent Eyles library at Bristol. This is a major collection started before it became a financial liability by two who became very able 'book hounds'. In later years, when it had become expensive to maintain and augment, it was still possible to support it from Joan's surprisingly capable business acumen on the Stock Exchange. For those of us privileged to have had her friendship, that, and her devoted help with our problems, will remain our memorial.

H.S. TORRENS

\title{
NIELS HUGH DE VAUDREY HEATHCOTE: 22 January $1895-23$ June 1985
}

Born in the Near East, where his father, the Reverend Herbert Heathcote, was an Anglican chaplain, Niels Heathcote never forgot the few words of Arabic that he learnt from his nurse. A less pleasant souvenir of his infancy was the malaria which attacked him from time to time throughout his long life. $\mathrm{He}$ was educated in England and, like many of his generation, joined the army not long after leaving school, a few months after the outbreak of the war of 1914-1918. After two years of overseas service in the Artists' Rifles, he became a lieutenant in the Royal Flying Corps (later the Royal Air Force), flying as an observer on the Western Front. He was shot down three times, once in flames, and also survived an encounter with Richthofen's Flying Circus-'there were twelve of them and one of us,' he told me, 'I didn't feel like firing first and neither did they.' Perhaps it is true that some of the airmen of the Great War were the last survivors of the age of chivalry.

After demobilization in 1919, Heathcote entered University College London (UCL) and graduated with honours in physics in 1922. For the next seventeen years he was a schoolmaster in London, finding time to attend postgraduate lectures at UCL in physics and in the recently founded Department of History and Method of Science, which was then headed by Professor Abraham Wolf. Heathcote also developed his talents as a linguist and, although he did not increase his knowledge of Arabic, he became competent in Latin, Greek and most West European and Scandinavian languages. 
He became particularly interested in the history of magnetism and electricity and in eighteenth-century theories of heat. His earliest publications, on the discovery of Ohm's Law (1931) and knowledge of magnetic variation before Columbus (1932) appeared in Science Progress, a journal which supported British historians of science before the foundation of Annals of Science, in which Heathcote's 'Early Nautical Charts' (1936) was one of the first papers. This was a year after the publication of The Discovery of Specific and Latent Heats (London, Arnold, 1935) which he wrote jointly with Douglas McKie, then a lecturer and later professor at UCL. Heathcote contributed the important chapters on the work of Krafft and Richmann in St Petersburg and Wilcke and Gadolin in Sweden.

On the outbreak of the Second World War in 1939, Heathcote re-joined the Royal Air Force and served with Army Co-operation Command and the Airborne Forces. He was attached to General Eisenhower's staff and was mentioned in despatches for distinguished service in connection with the airborne invasion of Normandy and the Arnhem operation. After retiring as a Squadron Leader in 1945 , he resumed his historical research and worked as a private tutor until 1947, when he was awarded his Ph.D., just before being appointed lecturer at UCL in the Department of the History and Philosophy of Science, as it was now called.

The work of the department had been suspended from 1939 to 1945 , when UCL was evacuated to Wales, and Heathcote joined it when it was expanding rapidly under its new Head, Professor Herbert Dingle. The principal activity was the teaching and supervision of postgraduate students, most of them parttime, and Heathcote enthusiastically and conscientiously played a full part in this work. He was promored to Senior Lecturer in 1957 , Reader in 1959 and retired in 1965. During these years at UCL his publications included another joint work with McKie, their annotated translation of William Cleghorn's 'De Igne' (Annals of Science, 1958, also published separately) and his own Nobel Prize Winners in Physics, 1901-1950 (New York, Schuman, 1953) which could only have been written by someone with a good knowledge of twentieth-century physics as well as a sense of history. Less well known is his account, written jointly with his colleague Angus Armitage, of 'The First International Polar Year, 1882-1883' in volume 1 of Annals of the International Geophysical Year (London, Pergamon, 1959).

Heathcote was a founder member of the British Society for the History of Science and the main editor of its Bulletin (1949-1960), the precursor of the British Journal for the History of Science. Some important articles and book reviews appeared in the Bulletin, but unfortunately it is rarely cited by historians of science. In 1952 Heathcote also joined the editorial board of Annals of Science. McKie was the principal editor, but failing health eventually forced him to play a less active part and after 1965 Heathcote selflessly edited Annals single-handed until the publishers found a new editor in 1974. This heavy burden made it impossible for him to finish several projected publications on the history of electricity, but the manuscript of his translation, prepared jointly with his wife Caroline (also a founder member of the Society), of Daniel Gralath's Geschichte der Electricität (Danzig, 1747-1757) has been deposited in the manuscript department of the UCL library, where it can be consulted.

Anyone seeing Heathcote only in the lecture room probably thought that he had always been in academic life, but in fact he was fifty-two when he joined the staff of UCL-only three years short of the age at which British academics are now encouraged to retire. His eleven years in the forces and his active involvement in the life of his parish-he and his wife were devout Anglicans-gave him a broader view of life than is possessed by many academics. He was a most helpful colleague, an excellent companion and a staunch friend. When old age forced him to give up academic work it was with characteristic generosity and without seeking any publicity that he divided his library, which contained some quite rare books, between UCL and two other universities where senior historians of science had been former students of his department.

W. A. SMEATON 